\title{
Decision Making of Full Speed, Slow Steaming, Extra Slow Steaming and Super Slow Steaming using TOPSIS
}

\author{
R.O. Saut Gurning ${ }^{1}$, Wolfgang Busse ${ }^{2}$, Mizan Lubnan ${ }^{3}$
}

\begin{abstract}
But in the beginning of the latest economic crisis on 2007, the containership fleet is slowing down. Even though world oil prices are now declining, but based on the prediction of World Bank, the price of oil will rise again in 2017. Even some shipping company implements slow steaming method on the operation of their ships. But they do not know whether these methods are effective or not due to any negative effects arising from an implement of slow steaming like increased sailing time so may result in losses to the shippers. This study aims to give suggestions on which ship speed is most optimal for shipping companies by considering technical and operational, financial and also environmental aspect then will be selected one by using Technique for Order of Preference by Similarity to Ideal Solution (TOPSIS) method. While for criteria and sub criteria weighting are calculated by Analytic Hierarchy Process (AHP) method using Expert Choice software. From the TOPSIS method, super slow steaming was chosen to be the first rank.
\end{abstract}

Keywords - Decision Making, Maritime Economic, Ship Speed, Slow Steaming, TOPSIS

II. METHODOLOGY

\section{INTRODUCTION}

B unker fuel is a considerable expense to shipping lines. Especially in 2007, when bunker costs soared (July 2007 to July 2008: 350-700 USD/ton) ship operational cost becomes higher, the liner shipping industry decreases the commercial speed of their ships to save bunker cost.

In shipping, the best method to decrease the operational costs are by reducing the fuel consumption. The reasons for this is due to fuel consumption costs contribute approximately $47 \%$ of a ship's total operating expense. [1]

This research aims to make a selection of the most efficient ship speed by using decision support system or a system that can help in decision-making on an organization by applying the method in accordance with the decisions selected. It can be assumed with comparing ship speed at full speed, slow steaming, extra slow steaming and super slow steaming by considering the elements of technical, financial and also environmental aspects. One approach that often used to resolve the issue of Multi-Criteria Decision Making (MCDM) is using technique for order of preference by similarity to ideal solution called (TOPSIS) method based on the concept that selected is the best alternative, not only has the shortest distance from positive ideal solution, but it also has the longest distance from negative ideal solution.

R.O. Saut Gurning, Department of Marine Engineering, Institut Teknologi Sepuluh Nopember, Surabaya, 60111, Indonesia. sautgurning1@yahoo.com

Wolfgang Busse, Hochschule Wismar, Germany. wolfgang.busse@hs-wismar.de

Mizan Lubnan, Department of Marine Engineering, Institut Teknologi Sepuluh Nopember, Surabaya, 60111, Indonesia. mizanlubnan@yahoo.com

\section{A. Determining Alternatives}

Most of ship are designed to sail at full speeds which around $85-90 \%$ of maximum engine load. Based on Figure 1. there are several ship speed when ships are sailing, there are full speed, slow steaming, extra slow steaming. [2] [3]

- Full speed

Full speed is the maximum speed of the ship that has been designed by engine manufacture. [2] Can be seen in the chart above the speed range for full speed is about 20 up to 25 knots.

\section{- Slow steaming}

The operation of ship below the normal speed capacity, about $15 \%$ load from normal speed. [3] Can be seen in Figure 1. the speed range for slow steaming is about 18 up to 20 knots.

\section{- Extra slow steaming}

The operation of ship below the slow steaming speed capacity, about $25 \%$ load from normal speed. [3] Can be seen in Figure 1. the speed range for extra slow steaming is about 17 up to 18 knots.

\section{- Super slow steaming}

This method also known as economic speed because it has a very significant change on fuel saving. Super slow steaming can use for higher reductions in operational ship speed. [3]

\section{B. Determining Criteria}

TOPSIS is one of method to select some alternatives based on same criteria. For this case, the criteria divided into 3 criteria and 7 sub-criteria.

These criteria have to decide carefully, because the criteria will influence the selected alternative mostly. Each group of the criteria has its associated sub criteria. All the criteria and sub-criteria will simplify the TOPSIS method to achieve the goal that is selecting the most efficient ship speed.

There are two possible goals for each sub criteria which 
are benefit or cost goal. The benefit goal are sub criteria that are profitable or advantageous such as a vessel's profits, while the cost goal are sub criteria that are disadvantageous such as the amount of emissions incurred by ship engine. Detail explanation of main criteria and sub criteria will be describe in Table 1 [2]

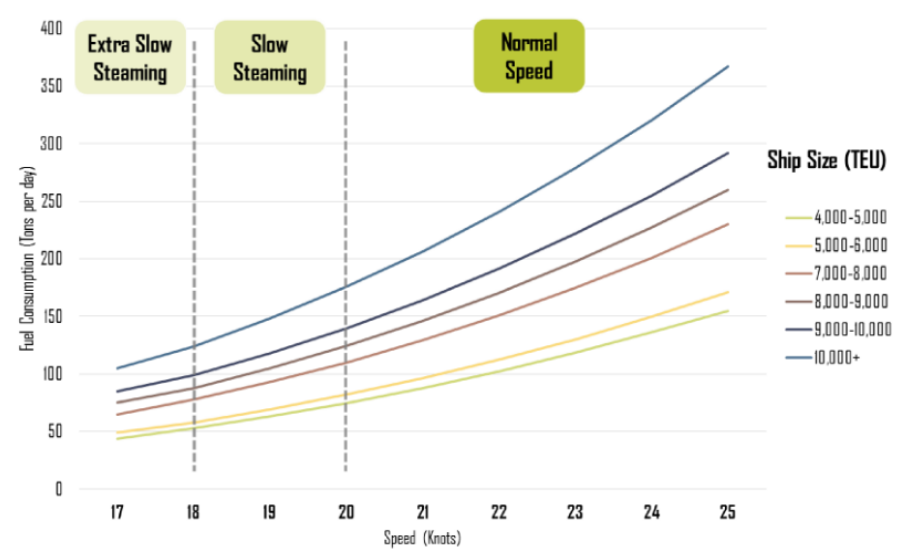

Figure 1. Fuel consumption by containership size and speed Source: (Dagkinis \& Nikitakos 2015)

TABLE 1 .

THE LIST OF CRITERIA AND SUB-CRITERIA ASSOCIATED WITH THE GOAL

\begin{tabular}{ccc}
\hline Main Criteria & Sub Criteria & Goal \\
\hline \multirow{2}{*}{$\begin{array}{c}\text { Technical and Operational } \\
\text { Aspect }\end{array}$} & Engine Efficiency & Benefit \\
\cline { 2 - 3 } Financial Aspect & Auxiliary Consumption & Cost \\
\cline { 2 - 3 } & Operational Cost & Cost \\
\hline \multirow{2}{*}{ Environmental Aspect } & Ship Revenue & Benefit \\
\cline { 2 - 3 } & Carbon Dioxide (CO2) & Cost \\
\cline { 2 - 3 } & Nitrogen Oxide (NOx) & Cost \\
\hline
\end{tabular}

Here is an explanation of each of the criteria and subcriteria in Table 1. are used in the selection of the ship's speed:

\section{Technical and Operational Aspect}

Which is the speed considerations that can work most optimally. The following sub criteria in the technical and operational aspect:

\section{a. Engine Efficiency}

Decreased engine efficiency due to low load operation of the engine. The efficiency of a machine is a measure of how well a machine can convert available energy from fuel to mechanical output energy.

b. Auxiliary Consumption

With increasing shipping time because the speed reduction will have an impact on the amount of fuel consumed by the auxiliary machinery.

\section{Financial Aspect}

Costs become a very important component for the management of companies involved in the implementation of activities to accomplish goals, including the ship's speed decisions. The following sub-criteria in financial calculations:

\section{a. Operational Cost}

Operational costs are the costs associated with the cost to run the operational aspects of the ship in order that the ship is always in a condition ready to sail. Costs are included in ship operating expenses are fuel cost, lubricant cost and also port cost.

b. Ship Revenue

Fee income earned from the shipment of goods from the origin port to destination port. The negative impact of slow steaming will cause reduced of the ship revenue.

\section{Environmental Aspect}

Environmental aspect is a consideration the effect from ship emissions on the surrounding environment. The following sub criteria of environmental aspects were taken into consideration in measuring the emissions caused by the combustion of fuel: 


\section{a. Carbon Dioxide $\left(\mathrm{CO}_{2}\right)$}

Carbon dioxide emissions during voyage activity is caused by fuel combustion in the engine of the ship. The amount of carbon dioxide levels can result in causing the hot air trapped on earth and eventually becomes hot environment.

\section{b. Nitrogen Oxide $\left(N O_{X}\right)$}

Nitrogen oxide compounds come from the combustion of the fossil fuels. The air has been polluted by nitrogen oxide gas is not only harmful to humans and animals, but also dangerous for the life of the plant.

c. Sulfur Dioxide $\left(\mathrm{SO}_{2}\right)$

Sulfur dioxide compounds formed during a combustion of fossil fuels containing sulfur. High levels of Sulfur dioxide in the air is one of the causes of acid rain.

\section{Engine Efficiency Calculation}

The efficiency of a machine is a measure of how well a machine can convert available energy from fuel to mechanical output energy. The percentage difference of the input power and the output power are efficiency values. For example, the electric power used to turn on the lights is not all converted into light energy, some of electrical power turned into heat. From Figure 2. efficiency can be defined as ratio between the amount of power required and the amount of power generated.

Then the efficiency value can be determined by using formula (1): [4]

$$
\eta \quad=\frac{P_{\text {aut }}}{P_{\text {ir }}} \times 100 \%
$$

Where,

$\eta \quad=$ Efficiency $(\%)$

$\mathrm{P}_{\text {out }}=$ Output power

$$
\mathrm{P}_{\text {in }}=\text { Input power }
$$

By using the formula (1), the calculation result can be seen in Table 2. the largest engine efficiency is at the time of slow steaming or $85 \%$ load from the normal load that is equal to $50.8 \%$.

\section{Auxiliary Consumption}

With increasing shipping time because the speed reduction will have an impact on the amount of fuel consumed by the auxiliary machinery. To calculate the total of auxiliary engine fuel consumption for each engine load are by using formula (2):

$$
\begin{array}{ll}
\mathrm{FC} & =\mathrm{P} \times \mathrm{SFOC} \times \mathrm{t} \\
\mathrm{Where} & \\
\mathrm{FC} & =\text { Fuel Consumption } \\
\mathrm{P} & =\text { Power developed in kilowatt } \\
\mathrm{SFOC} & =\text { Specific fuel oil consumption }(\mathrm{gr} / \mathrm{kwh}) \\
\mathrm{t} & =\text { Auxiliary engine operation time }
\end{array}
$$

When sailing conditions, auxiliary engine load is at $75 \%$. The first step to calculate the consumption of auxiliary engines 2017 by multiplying the number of auxiliary engine output with the specific fuel oil consumption (SFOC) on the auxiliary engine test record and also by multiplying with the total time spent when shipping and at port. By using the formula (2), the calculation result can be seen in Table 3 .

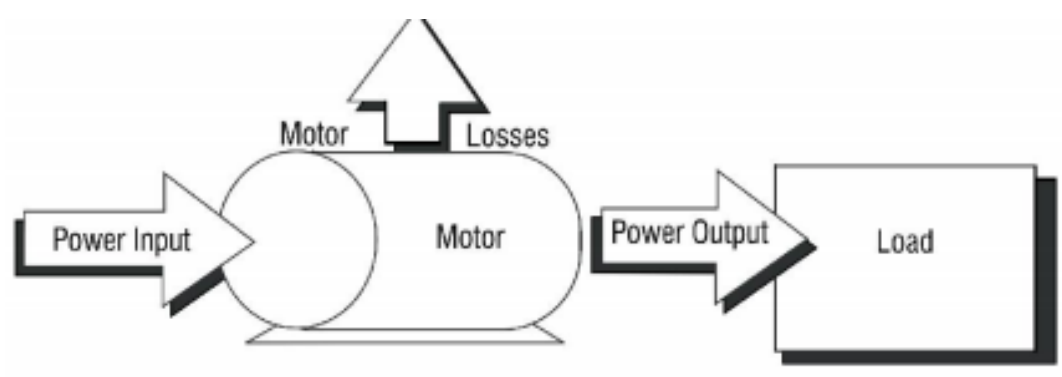

Figure 2. Input power and output power diagram Source: (Ghazali 2011)

TABLE 2.

ENGINE EFFICIENCY CALCULATION

\begin{tabular}{lcccc}
\hline & SSS & ESS & SS & FS \\
\hline Load & $50 \%$ & $75 \%$ & $85 \%$ & $100 \%$ \\
\hline Power (KW) & 4994 & 7491 & 8489,8 & 9988 \\
\hline FO Consump. (kg/h)MGO & 876,6 & 1276,9 & 1445,7 & 1739,8 \\
\hline FO Consump. (kg/h) HFO & 962,1 & 1401,5 & 1586,7 & 1909,5 \\
\hline SFOC (g/KWh) MGO & 180 & 174,03 & 173 & 176 \\
\hline Input Power (KW) & 2,05 & 1,98 & 1,97 & 2,00 \\
\hline Efficiency Engine (\%) & 48,8 & 50,5 & 50,8 & 49,9 \\
\hline
\end{tabular}


TABLE 3

AUXILIARY CONSUMPTION CALCULATION

\begin{tabular}{lcccc}
\hline & SSS & ESS & SS & FS \\
\hline $\begin{array}{l}\text { Shipping time } \\
\text { (hours) }\end{array}$ & 231,7 & 202,7 & 194,1 & 183,8 \\
\hline $\begin{array}{l}\text { Port Time } \\
\text { (hours) }\end{array}$ & 384 & 384 & 384 & 384 \\
\hline $\begin{array}{l}\text { 1 AE. FC } \\
\text { (ton/month) }\end{array}$ & 65,78 & 62,68 & 61,76 & 60,66 \\
\hline $\begin{array}{l}\text { Total FC } \\
\text { (ton/month) }\end{array}$ & 131,57 & 125,37 & 123,54 & 121,33 \\
\hline
\end{tabular}

\section{Operational Cost}

Operational cost of the ship as a cost related with the cost of operating for operational aspects. Operational costs consist of only fixed costs and not variable costs, which are actually depending on the length of time the ship sailed.

\section{Port Cost}

Port is a place consisting of land and surrounding waters with certain limits as a place of government activity and economic activity which is used as a place for mooring, anchorage, docking, loading and unloading of passengers or goods equipped with shipping safety facilities and supporting activities [5]. While the port cost is cost that should incurred by ship owner for the continued use of the port such as anchorage services, pilotage services, tugboat services and mooring services.

2. Bunker Fuel Cost

Consumption costs for shipping are the largest and most important part of the total operating costs, with fuel costs being the largest part of the consumption costs [6]. Ship fuel consumption are determined by several variables such as size of the ship, shipping distance, speed and weather (waves, currents, wind). To calculate the fuel consumptiont are by using formula (3):

$\mathrm{FC}=\mathrm{P} \times \mathrm{SFOC} \times \mathrm{t}$

Where,

FC = Fuel Consumption

$\mathrm{P} \quad=$ Power developed in kilowatt

SFOC $=$ Specific fuel oil consumption $(\mathrm{gr} / \mathrm{kwh})$

$\mathrm{t} \quad=$ Engine operation time

To get the value of SFOC can be calculated using data from fuel oil consumption during engine test bed divided by engine power developed. After getting the amount of fuel consumption, then it can be multiplied by fuel oil $180 \mathrm{cSt}$ prices for Rp. $6.350,00 /$ litre. Table 4. contains the result of fuel consumption for each engine load in a month. Can be concluded that super slow steaming greatly affects the amount of bunker fuel cost by reducing up to Rp. 735.990.000 from normal operational load. Then after get the cost of fuel consumption of MV. Meratus Medan 1 for one month, the next step is sum it with the total port cost for a month. Table 5. contains total operational cost at each speed. Can be concluded that slow steaming or decrease the ship engine load is proven to reduce the operational cost that should be paid by the ship owner. Even a 50\% decrease in ship engine load can reduce operational cost by up to $\mathrm{Rp}$. $740,000,000$.

\section{Ship Revenue}

Ship revenue is the amount of vessel revenue earned from total freight services less the operational cost. The negative impact of slow steaming will cause reduced of the ship revenue.

\section{Service Performance}

Service Performance is the amount of cargo that can be delivered by ship within one month. To calculate the service Performance are by using formula (4): [6]

$$
\begin{aligned}
& \text { Fs }=\text { cap }_{\text {eff }} \cdot \mathrm{f}_{\mathrm{T}} \\
& \text { Fs }=\text { cap }_{\text {eff }} \cdot \mathrm{TO} /(\mathrm{TH}+\mathrm{TS}) \\
& \text { Where, } \\
& \text { Fs }=\text { Service Performance } \\
& \text { cap }_{\text {eff }}=\text { Effective Capacity }(\rho=0,87) \\
& \mathrm{f}_{\mathrm{T}}=\text { Maximum Number of Roundtrips } \\
& \mathrm{TO}=\text { Operating Time } \\
& \mathrm{TH}=\text { Harbor Waiting Time } \\
& \mathrm{TS}=\text { Sea (Shipping) Time }
\end{aligned}
$$

Effective capacity value obtained by multiplying the number of TEU'S on MV. Meratus Medan1 is 1001 TEUs with a constant value of effective capacity in a container ship that is 0.87 . To find a number of roundtrips maximum value can be calculated by operational time (To) divided by the amount of time between voyage time (Ts) with a port time (Th). In this calculation assumed operational time period and the waiting time at the port are same on each engine load.

2.Vessel Income

Vessel income is the amount of money received by shipping company from their activities of carrying out the delivery services to customers. In this research assumed vessel capacity is fully utilized. The formula used to calculate the vessel income are (5): [6]

$\mathrm{I}_{\mathrm{V}} \quad=\sum \mathrm{P}_{\mathrm{FR}, \mathrm{i}} \cdot \mathrm{F}_{\mathrm{S}}$

Where,

$\mathrm{I}_{\mathrm{V}} \quad=$ Vessel Income

$\mathrm{P}_{\mathrm{FR}, \mathrm{i}}=$ Freights Rates

$\mathrm{F}_{\mathrm{s}} \quad=$ Service Performance

The next step is to decrease the amount of operational cost at the same load so that it gets the value of ship revenue for one month. Table 6 . describes the amount of vessel income, operational cost and ship revenue. Can be concluded that full speed get more ship revenue than slow steaming, extra slow steaming and super slow steaming. This is because in slow steaming conditions only gets little vessel income 
International Journal of Marine Engineering Innovation and Research, Vol. 2(1), Dec. 2017. 41-50 (pISSN: 2541 -

TABLE 4.

BUNKER FUEL CALCULATION

\begin{tabular}{lcccc}
\hline & SSS & ESS & SS & FS \\
\hline Bunker Fuel Cost (Rp.) & 1.334 .540 .591 & 1.693 .196 .552 & 1.827 .250 .408 & 2.070 .531 .108 \\
\hline Port Cost (Rp.) & 113.821 .475 & 113.821 .475 & 113.821 .475 & 113.821 .475 \\
\hline Operational Cost (Rp. ) & 1.448 .362 .066 & 1.807 .018 .027 & 1.941 .071 .883 & 2.184 .352 .583 \\
\hline
\end{tabular}

TABLE 5 .

TOTAL OPERATIONAL COST

\begin{tabular}{ccccc}
\hline & $\begin{array}{c}\text { Service } \\
\text { Performance }\end{array}$ & $\begin{array}{c}\text { Vessel Income } \\
\text { (Rp.) }\end{array}$ & $\begin{array}{c}\text { Operational Cost } \\
\text { (Rp.) }\end{array}$ & $\begin{array}{c}\text { Ship Revenue } \\
\text { (Rp.) }\end{array}$ \\
\hline FS & 1126,09 & 21.170 .426 .167 & 2.184 .352 .583 & $18.986 .073 .583,29$ \\
\hline SS & 1105,56 & 20.784 .515 .550 & 1.941 .071 .883 & $18.843 .443 .666,90$ \\
\hline ESS & 1089,16 & 20.476 .281 .643 & 1.807 .018 .027 & $18.669 .263 .615,58$ \\
\hline SSS & 1036,94 & 19.494 .387 .411 & 1.448 .362 .066 & $18.046 .025 .344,50$ \\
\hline
\end{tabular}

TABLE 6.

SHIP REVENUE CALCULATION

\begin{tabular}{lcccc}
\hline & SSS & ESS & SS & FS \\
\hline Load & $50 \%$ & $75 \%$ & $85 \%$ & $100 \%$ \\
\hline Power (KW) & 4994 & 7491 & 8490 & 9988 \\
\hline Engine Speed (RPM) & 100,87 & 115,30 & 120,37 & 127,14 \\
\hline Activity (Hours) & 231,69 & 202,70 & 194,16 & 183,82 \\
\hline SFOC(g/KWh) HFO & 180,00 & 174,03 & 173,00 & 176,00 \\
\hline Fuel Cons. (ton) & 208,27 & 264,25 & 285,17 & 323,13 \\
\hline Fuel Cons. (litre) & 210163,9 & 266645,1 & 287756,0 & 326067,9 \\
\hline Price (Rp.) & 1.334 .540 .591 & $1.693 .196 .552,15$ & $1.827 .250 .407,80$ & 2.070 .531 .108 \\
\hline
\end{tabular}

TABLE 7.

FUEL CORRECTION FACTORS FOR $\mathrm{NO}_{\mathrm{x}} \mathrm{AND} \mathrm{SO}_{2}$

\begin{tabular}{lccc}
\hline \multicolumn{1}{c}{ Engine } & Model Year & NO $_{\mathbf{x}}$ & SO $_{2}$ \\
\hline Slow Speed Diesel & $\leq 1999$ & 18.1 & 10.5 \\
\hline Medium Speed Diesel & $\leq 1999$ & 14.0 & 11.5 \\
\hline Slow Speed Diesel & $2000-2010$ & 17.0 & 10.5 \\
\hline Medium Speed Diesel & $2000-2010$ & 13.0 & 11.5 \\
\hline Slow Speed Diesel & $2011-2015$ & 14.4 & 10.5 \\
\hline Medium Speed Diesel & $2011-2015$ & 10.5 & 11.5 \\
\hline Gas Turbine & All & 6.1 & 16.5 \\
\hline Steamship & All & 2.1 & 16.5 \\
\hline
\end{tabular}

Source: Puget Sound Maritime Air Emission Inventory

TABLE 8.

FUEL CORRECTION FACTORS FOR $\mathrm{CO}_{2}$

\begin{tabular}{lll}
\hline \multicolumn{1}{c}{ Engine } & Model Year & $\mathbf{C O}_{2}$ \\
\hline Slow Speed Diesel & All & 620 \\
\hline Medium Speed Diesel & All & 683 \\
\hline Gas Turbine & All & 970 \\
\hline Steamship & All & 970 \\
\hline \multicolumn{2}{c}{ Source: Puget Sound Maritime Air Emission Inventory } \\
\end{tabular}

Source: Puget Sound Maritime Air Emission Inventory 
TABLE 9

FUEL CORRECTION FACTORS

\begin{tabular}{cccc}
\hline Fuel Used & NO $_{\mathbf{x}}$ & $\mathbf{S O}_{2}$ & $\mathbf{C O}_{2}$ \\
\hline HFO $(2.7 \% \mathrm{~S})$ & 1 & 1 & 1 \\
\hline $\operatorname{HFO}(1.5 \% \mathrm{~S})$ & 1 & 0.555 & 1 \\
\hline MGO $(0.5 \% \mathrm{~S})$ & 0.94 & 0.185 & 1 \\
\hline MDO $(1.5 \% \mathrm{~S})$ & 0.94 & 0.555 & 1 \\
\hline MGO $(0.1 \% \mathrm{~S})$ & 0.94 & 0.037 & 1 \\
\hline MGO $(0.3 \% \mathrm{~S})$ & 0.94 & 0.111 & 1 \\
\hline MGO $(0.4 \% \mathrm{~S})$ & 0.94 & 0.148 & 1 \\
\hline
\end{tabular}

Source: Puget Sound Maritime Air Emission Inventory

TABLE 10 .

SHIP EMISSIONS CALCULATION

\begin{tabular}{ccccc}
\hline & SSS & ESS & SS & FS \\
\hline Power (KW) & 4994 & 7491 & 8490 & 9988 \\
\hline RPM & 100,87 & 115,30 & 120,37 & 127,14 \\
\hline Speed (knot) & 15,65 & 17,89 & 18,68 & 19,73 \\
\hline LF & 0,50 & 0,75 & 0,85 & 1,00 \\
\hline Activity (hours) & 231,69 & 202,70 & 194,16 & 183,82 \\
\hline Energy (kWh) & 577828 & 1132464,2 & 1398814,2 & 1835984,5 \\
\hline $\mathrm{NO}_{x}$ (ton/month) & 10,46 & 20,50 & 25,32 & 33,23 \\
\hline $\mathrm{SO}_{2}$ (ton/month) & 6,07 & 11,89 & 14,69 & 19,28 \\
\hline $\mathrm{CO}_{2}$ (ton/month) & 358,25 & 702,13 & 867,26 & 1138,31 \\
\hline
\end{tabular}

\section{E. Ship Emissions}

The advantage of slow steaming is to decrease the amount of $\mathrm{CO}_{2}$ emissions that are proportional with the amount of fuel combustion [7]. To calculate an estimate of the ship's emissions, it can use the method of Puget Sound Maritime Air Emission Inventory that published in 2012. The formula used to calculate the emissions from the engine are (6): [8]

$\mathrm{E}=$ Energy $\times \mathrm{EF} \times \mathrm{FCF}$

Where,

$\mathrm{E} \quad=$ Emissions from the engine

Energy $=$ Energy demand $(\mathrm{kWh})$

$\mathrm{EF} \quad=$ Emission factor $(\mathrm{g} / \mathrm{kWh})$

$\mathrm{FCF}=$ Fuel Correction Factor

In calculating the estimated emissions of ships, the value needed are energy $(\mathrm{kWh})$, emission factor $(\mathrm{g} / \mathrm{kWh})$ and fuel correction factor.

To get the energy value are by multiplying the load factor with a maximum continuous rated engine power (MCR) and also the duration of ship activity. Whereas for emission factors (EF) are listed by model year for slow and medium speed engines on the Table 7. and Table 8. Fuel correction factors are used to account for variations in fuel parameters between different types of fuel, so these variations can be accounted for in the emission estimates. Can be seen in the Table 9. lists the fuel correction factors.
The result of the calculation of the total $\mathrm{CO}_{2}, \mathrm{NO}_{\mathrm{X}}$ and $\mathrm{SO}_{2}$ emissions at the MV. Meratus Medan 1 in one month can be seen in the Table 10. Can be concluded that super slow steaming or decrease the ship engine load is greatly affects to reduction the ship emission that produced by the engine. The amount of ship emissions are 10,46 ton/month for $\mathrm{NO}_{\mathrm{x}}, 6,07$ ton/month for $\mathrm{SO}_{2}$ and 358,25 for $\mathrm{CO}_{2}$.

\section{F. Processing Questionnaire Data}

TOPSIS method requires input data that are weights for each criteria and each sub criteria in order to choose the best alternative. Based on the flowchart of selection methodology, we have to make questionnaire. Then the questionnaire filled by respondents working in PT. Meratus who understand this field. Respondents will give a value on each criteria and each sub criteria between the numbers 1 to 9 represent the important of one criteria with another. Then pairwise comparison matrix is used to assess the importance (weighting) of each criteria and each sub criteria by using expert choice software. Table 11 shows weight of each criteria and sub criteria from the results of questionnaire processing using expert choice software.

The next step is to multiply each weighting sub criteria values with each criteria values. In order for the weights on each sub criteria if summed each other, the total value remains one. The normalized weighting values of all other sub-criteria are obtained as shown in the Table 12. 
G. Selection Decisions

After the normalized weighting values for each criteria and sub criteria, then the selection of the best alternative can be done by using TOPSIS method. In TOPSIS method, the optimal alternative is closest to the positive ideal solution and farthest from the negative ideal solution, as shown in the Figure 3. The reasons for using TOPSIS method are conceptually simple, computational efficiency and has the ability to measure relative performance of the alternatives in decision of a simple mathematical form. [9]

TABLE 11.

THE WEIGHTING VALUES OF ALL CRITERIA AND SUB CRITERIA

\begin{tabular}{|c|c|c|c|}
\hline & & $\begin{array}{c}\text { Sub Criteria } \\
\text { Values }\end{array}$ & $\begin{array}{c}\text { Criteria } \\
\text { Values }\end{array}$ \\
\hline Technical \& Operational & & & 0,323 \\
\hline Engine Efficiency & $=$ & 0,723 & \\
\hline \multirow[t]{2}{*}{ Auxiliary Consumption } & $=$ & 0,277 & \multirow{2}{*}{+} \\
\hline & $=$ & 1 & \\
\hline Financial & & & 0,514 \\
\hline Operational Cost & $=$ & 0,376 & \\
\hline \multirow[t]{2}{*}{ Ship Revenue } & $=$ & 0,624 & \multirow{2}{*}{+} \\
\hline & $=$ & 1 & \\
\hline Environmental & & & 0,164 \\
\hline Carbon Dioxide & $=$ & 0,536 & \\
\hline Nitrogen Oxide & $=$ & 0,160 & \\
\hline \multirow[t]{3}{*}{ Sulphur Dioxide } & $=$ & 0,303 & \multirow{2}{*}{+} \\
\hline & $=$ & 1 & \\
\hline & & & 1 \\
\hline
\end{tabular}

TABLE 12.

THE NORMALIZED WEIGHTING VALUES OF ALL THE CRITERIA

\begin{tabular}{ccccccc}
\hline $\begin{array}{c}\text { Engine } \\
\text { Efficiency }\end{array}$ & $\begin{array}{c}\text { Auxiliary } \\
\text { Consumption }\end{array}$ & $\begin{array}{c}\text { Operational } \\
\text { Cost }\end{array}$ & $\begin{array}{c}\text { Ship } \\
\text { Revenue }\end{array}$ & NO $_{\mathbf{x}}$ & $\mathbf{S O}_{\mathbf{2}}$ & $\mathbf{C O}_{\mathbf{2}}$ \\
\hline 0,2335 & 0,0895 & 0,1933 & 0,3207 & 0,0262 & 0,0497 & 0,0879 \\
\hline
\end{tabular}

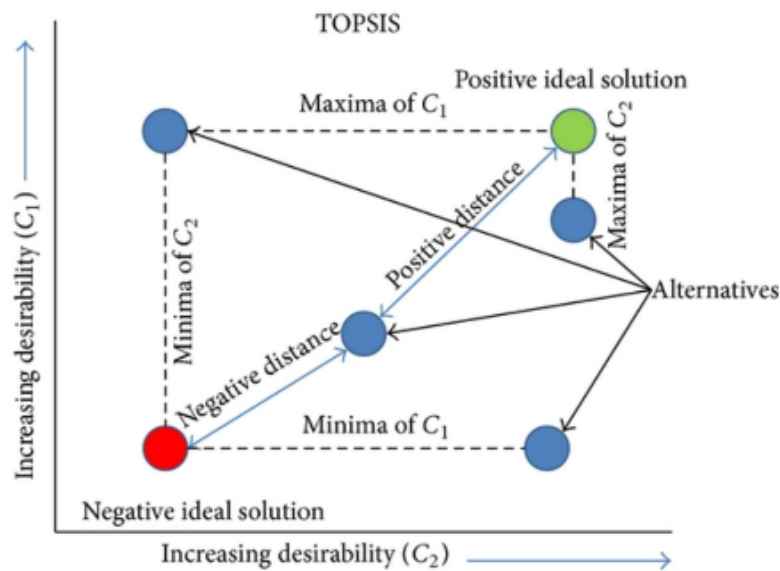

Figure 3. Illustration of distance to positive ideal solution and negative ideal solution Source: Chauhan \& Vaish 2013

TABLE 13.

THE NORMALIZED DECISION MATRIX

\begin{tabular}{cccccccc}
\hline Engine & $\begin{array}{c}\text { Auxiliary } \\
\text { Efficiency }\end{array}$ & $\begin{array}{c}\text { Operational } \\
\text { Consumption }\end{array}$ & $\begin{array}{c}\text { Ship } \\
\text { Revenue }\end{array}$ & $\mathbf{N O}_{\mathbf{x}}$ & $\mathbf{S O}_{\mathbf{2}}$ & $\mathbf{C O}_{\mathbf{2}}$ \\
\hline FS & 0,4991 & 0,4834 & 0,5858 & 0,5093 & 0,6967 & 0,6967 & 0,6967 \\
SS & 0,5078 & 0,4922 & 0,5206 & 0,5055 & 0,5308 & 0,5308 & 0,5308 \\
ESS & 0,5048 & 0,4994 & 0,4846 & 0,5008 & 0,4298 & 0,4298 & 0,4298 \\
SSS & 0,4880 & 0,5241 & 0,3884 & 0,4841 & 0,2193 & 0,2193 & 0,2193 \\
\hline
\end{tabular}


TABLE 14.

THE WEIGHTED NORMALIZED DECISION MATRIX

\begin{tabular}{cccccccc}
\hline & $\begin{array}{c}\text { Engine } \\
\text { Efficiency }\end{array}$ & $\begin{array}{c}\text { Auxiliary } \\
\text { Consumption }\end{array}$ & $\begin{array}{c}\text { Operational } \\
\text { Cost }\end{array}$ & $\begin{array}{c}\text { Ship } \\
\text { Revenue }\end{array}$ & $\mathbf{N O}_{\mathbf{x}}$ & $\mathbf{S O}_{2}$ & $\mathbf{C O}_{2}$ \\
\hline FS & 0,1166 & 0,0432 & 0,1132 & 0,1633 & 0,0183 & 0,0346 & 0,0612 \\
SS & 0,1186 & 0,0440 & 0,1006 & 0,1621 & 0,0139 & 0,0264 & 0,0467 \\
ESS & 0,1179 & 0,0447 & 0,0937 & 0,1606 & 0,0113 & 0,0214 & 0,0378 \\
SSS & 0,1140 & 0,0469 & 0,0751 & 0,1553 & 0,0058 & 0,0109 & 0,0193 \\
\hline
\end{tabular}

Steps to solve a problem using TOPSIS method are as follows:

1. Construct the normalized decision matrix $\left(r_{i j}\right)$

Normalized decision matrix is a division between the matrix value with the sum value from each alternative value in the sub criteria. The formula used to calculate the normalized decision matrix $\left(\mathrm{r}_{\mathrm{ij}}\right)$ are $(7)$ : [10]

$$
\mathrm{r}_{\mathrm{ij}} \quad=\frac{x_{i j}}{\sqrt{\Sigma_{i j}^{2}}}
$$

Where,

$$
\begin{array}{ll}
\mathrm{i} & =\text { (alternatives }) 1,2 \ldots ., \mathrm{m} ; \\
\mathrm{j} & =(\text { criteria }) 1,2 \ldots, \mathrm{n} ;
\end{array}
$$

Furthermore, by using formula (7) the normalized decision matrix values of all alternative and sub-criteria are obtained as shown in Table 13.

\section{Calculate the weighted normalized decision matrix $\left(y_{i j}\right)$}

The weighted normalized decision matrix is the multiplication of the normalized decision matrix value with the weight of each sub criteria. The formula used to calculate the weighted normalized decision matrix $\left(\mathrm{y}_{\mathrm{ij}}\right)$ are (8): [10]

$$
\begin{aligned}
& \mathrm{Y}_{\mathrm{ij}}=\mathrm{w}_{\mathrm{i}} \times \mathrm{r}_{\mathrm{ij}} ; \\
& \text { Where, } \\
& \begin{array}{ll}
\mathrm{i} \quad=(\text { alternatives }) 1,2 \ldots ., \mathrm{m} ; \\
\mathrm{j} \quad=(\text { criteria }) 1,2 \ldots ., \mathrm{n} ;
\end{array}
\end{aligned}
$$

TABLE 15.

THE POSITIVE IDEAL SOLUTION (A+) AND NEGATIVE IDEAL SOLUTION (A-)

\begin{tabular}{cccccccc}
\hline & Benefit & Cost & Cost & Benefit & Cost & Cost & Cost \\
\hline $\begin{array}{c}\text { Engine } \\
\text { Efficiency }\end{array}$ & $\begin{array}{c}\text { Auxiliary } \\
\text { Consumption }\end{array}$ & Operational Cost & $\begin{array}{c}\text { Ship } \\
\text { Revenue }\end{array}$ & NO $_{\mathbf{x}}$ & SO $_{2}$ & $\mathbf{C O}_{2}$ \\
\hline FS & 0,1166 & 0,0432 & 0,1132 & 0,1633 & 0,0183 & 0,0346 & 0,0612 \\
\hline SS & 0,1186 & 0,0440 & 0,1006 & 0,1621 & 0,0139 & 0,0264 & 0,0467 \\
\hline ESS & 0,1179 & 0,0447 & 0,0937 & 0,1606 & 0,0113 & 0,0214 & 0,0378 \\
\hline SSS & 0,1140 & 0,0469 & 0,0751 & 0,1553 & 0,0058 & 0,0109 & 0,0193 \\
\hline & & RESULT & & & & \\
\hline A+ & 0,1186 & 0,0432 & 0,0751 & 0,1606 & 0,0058 & 0,0109 & 0,0193 \\
\hline A- & 0,1140 & 0,0469 & 0,1132 & 0,1553 & 0,0183 & 0,0346 & 0,0612 \\
\hline
\end{tabular}

Furthermore, by using formula (8) the weighted normalized decision matrix values of all sub-criteria are obtained as shown in Table 14.

3. Determine the positive ideal solution (PIS) and negative ideal solution (NIS)

Positive ideal solution (PIS) is the maximum value of benefit criteria and also the minimum value of cost criteria while negative ideal solution (NIS) is the minimum value of benefit criteria and also the maximum value of cost criteria. The formula used to find the value of positive ideal solution (PIS) and negative ideal solution (NIS) are (9): [10]

$$
\begin{aligned}
& A^{+}=\mathrm{y}_{1}^{+}, \mathrm{y}_{2}{ }^{+}, \ldots, \mathrm{y}_{\mathrm{j}}^{+} \\
& \text {A- } \quad=\mathrm{y}_{1}{ }^{-}, \mathrm{y}_{2}^{-}, \ldots, \mathrm{y}_{\mathrm{j}}^{-} \\
& \text {Where, } \\
& \begin{array}{l}
\mathrm{J}^{+} \quad=\{\mathrm{j}=1,2,3, \ldots, \mathrm{n} \text { and } \mathrm{j} \text { is benefit criteria }\} \\
\mathrm{J}^{-} \quad=\{\mathrm{j}=1,2,3, \ldots, \mathrm{n} \text { and } \mathrm{j} \text { is cost criteria }\}
\end{array}
\end{aligned}
$$

The output values of positive ideal solution (PIS) are summarized in Table 15 by using blue color whereas for output values of negative ideal solution (NIS) are summarized by using red color. The goal of each criteria in the positive ideal solution (PIS) changes to the opposite way from the negative ideal solution (NIS), for instance, from "Benefit" to "Cost" and the other way around. 
TABLE 16.

\begin{tabular}{ccc}
\multicolumn{2}{c}{ THE DISTANCE SEPARATION MEASURE OF EACH ALTERNATIVE } \\
\hline & $\mathbf{D}^{+}$ & $\mathbf{D}^{-}$ \\
\hline FS & 0,0628 & 0,0092 \\
SS & 0,0414 & 0,0231 \\
ESS & 0,0289 & 0,0347 \\
SSS & 0,0100 & 0,0627 \\
\hline
\end{tabular}

TABLE 17.

RANK THE PREFERENCE ALTERNATIVES

\begin{tabular}{ccc}
\hline Result & V & Rank \\
FS & 0,1283 & 4 \\
SS & 0,3587 & 3 \\
ESS & 0,5455 & 2 \\
SSS & 0,8625 & 1 \\
\hline
\end{tabular}

4. Calculate the distance of positive ideal solution $\left(D^{+}\right)$ and negative ideal solution $\left(D^{-}\right)$

The distance of positive ideal solution is square root result from the reduction of positive ideal solution on each criteria with weighted normalized. The negative ideal solution has the same steps as the ideal positive solution. Formula used to find the distance of positive ideal solution and negative ideal solution are (10): [10]

$$
\begin{gathered}
D_{i}^{+}=\sqrt{\sum_{i=1}^{+1}\left(y_{i}^{+}-y_{i j}\right)^{2}} \\
D_{i}^{-}=\sqrt{\sum_{i=1}^{+1}\left(y_{i j}-y_{i}^{-}\right)^{2}}
\end{gathered}
$$

Where,

$$
\mathrm{y}_{\mathrm{ij}} \quad=\text { the weighted normalized decision matrix }
$$

The output values of the positive ideal solution distance $\left(\mathrm{D}^{+}\right)$and negative ideal solution $\left(\mathrm{D}^{-}\right)$are summarized in Table 16.

\section{Calculate the relative closeness to the ideal solution}

The final stage of TOPSIS method is to calculate the preference value of each alternative. The best alternative of the steaming speed will be chosen by shipping companies based on the value closest to one which has the shortest distance from the PIS point and the farthest distance from the NIS point. Formula used to find the relative closeness to the ideal solution are (11): [10]

$$
V_{i}^{+}=\frac{D_{i}^{-}}{D_{i}^{+}+D_{i}^{-}}
$$

Then by using the formula 11 , will get the values of relative closeness to ideal solution for all alternatives. The relative closeness to ideal solution values are mentioned in Table 17., it can be concluded that such an alternative is the most efficient steaming speed of liner business industry into consideration all criteria described. The full ranking of all alternatives is as follows: 1) $\mathrm{SSS}>2$ ) $\mathrm{ESS}>3$ ) $\mathrm{SS}>4$ ) FS.

\section{CONCLUSION}

Based on the results of the discussion in this report which refers to the relevant data and references, it can be concluded for the results of studies that have been implemented are as follows:

1. The speed of ship is the most important factor affecting the operational activities of ship both in terms of operational costs and also the ship revenue. From the most efficient steaming speed, it could help shipping companies to saving of fuel, which results a reduction of fuel costs.

2. From the calculation for choosing the most efficient steaming speed based on the multiple criteria requirement by using TOPSIS (technique for order preference by similarity to ideal solution), to sort alternatives from the largest value to the smallest value, so expected the most efficient ship speed will be chosen. Then from the TOPSIS method gives the following results:

a. By using TOPSIS method, super slow steaming was chosen to be the first rank with a value of 0,8625 while the next rank is extra slow steaming slow steaming with a value of 0,5455 , slow steaming with a value of 0,3587 , full speed with a value of 0,1283 .

b. Super slow steaming can be ranked first due to the very large difference in the number of ship emissions generated during the super slow steaming conditions.

c. TOPSIS method suitable for selection of a simple alternative with criteria and sub criteria that are not too much because there is no software that can be used.

d. By using expert choice software, can be known the weight of criteria and sub criteria which have 
been determined. From the result of weighting analysis on each criteria, it can be concluded that financial are in the first priority with a weight of 0,514 , then technical and operational with a weight of 0,323 and environmental with a weight of 0,164 .

3. There are several things that need to be done related to slow steaming analysis in order to develop this thesis in the future. The suggestions in this thesis are:

a. Questionnaires to obtain data in priority weighting on each criteria of the most optimal speed should be distributed to more respondents and diverse so that the data obtained more balanced.

b. The present study can be extended by analyzing the influence of slow steaming on the engine, because in the slow steaming conditions engine should work under normal conditions that has been designed by engine manufacture.

\section{REFERENCES}

[1] R. S. G. A. D. D. Farin Valentito, "Optimasi Skenario Bunkering dan Kecepatan Kapal pada Pelayaran Tramper," JURNAL TEKNIK POMITS, vol. 1, p. 1, 2012.

[2] A. Rahman, "A Decision Making Support Of The Most Efficient Steaming Speed For The Liner Business Industry," European Journal of Business and Management, vol. 4, pp. 37-49, 2012.

[3] M. P. P. B. Marina Zanne, "Environmental and Economic Benefts of Slow Steaming," Transaction On Maritime Science, vol. 02, pp. 123-127, 2013.

[4] R. A. Ghazali, "Metode Perhitungan Efisiensi Motor Induksi Yang Sedang Beroperasi," Univrsitas Indonesia, Depok, 2011.

[5] Republik Indonesia, UU 17 Tahun 2008 Tentang Pelayaran, 2008.

[6] J. Meyer, R. Stahlbock and S. Vos, "Slow Steaming in Container Shipping," in 45th Hawaii International Conference on System Sciences, 2012.

[7] P. Cariou, "Is Slow Steaming a Sustainable Means of Reducing $\mathrm{CO} 2$ Emissions From Container Shipping?," Transportation Research Part D: Transport and Environment, vol. 16, no. 3, pp. 260-264, 2011.

[8] Starcrest Consulting Group, LLC, "Puget Sound Maritime Air Emission Inventory 2012," Puget, 2012.

[9] Murnawan and A. F. Siddiq, "Sistem Pendukung Keputusan Menggunakan Metode Technique for Order by Similarity to Ideal Solution (TOPSIS)," Jurnal Sistem Informasi (JSI), vol. 04, pp. 398-412, 2012.

[10] R. F. N. N. F. Hosseinzadeh Lotfi, "Ranking Efficient Units in DEA by Using TOPSIS Method," Applied Mathematical Sciences, vol. 5, pp. 805-815, 2011.

[11] Pitana Trika, R. O. Saut Gurning, Fauzan Fikri "Modeling of LPG Distribution in Western of Indonesia using Discrete Simulation Method," International Journal of Marine Engineering and Innovation Research, vol. 1 (3), pp. 128-135, 2017. 